\title{
Comparison of automated ribosomal intergenic spacer analysis (ARISA) and denaturing gradient gel electrophoresis (DGGE) techniques for analysing the influence of diet on ruminal bacterial diversity
}

\author{
Cristina Saro, Eduarda Molina-Alcaide, Leticia Abecia, María José \\ Ranilla and María Dolores Carro
}

\begin{abstract}
The objective of this study was to compare the automated ribosomal intergenic spacer analysis (ARISA) and the denaturing gradient gel electrophoresis (DGGE) techniques for analysing the effects of diet on diversity in bacterial pellets isolated from the liquid (liquid-associated bacteria (LAB)) and solid (solid-associated bacteria $(S A B)$ ) phase of the rumen. The four experimental diets contained forage to concentrate ratios of 70:30 or 30:70 and had either alfalfa hay or grass hay as forage. Four rumen-fistulated animals (two sheep and two goats) received the diets in a Latin square design. Bacterial pellets ( $L A B$ and $S A B$ ) were isolated at $2 \mathrm{~h}$ post-feeding for DNA extraction and analysed by ARISA and DGGE. The number of peaks in individual samples ranged from 48 to 99 for $L A B$ and from 41 to 95 for SAB with ARISA, and values of DGGEbands ranged from 27 to 50 for $\angle A B$ and from 18 to 45 for $S A B$. The LAB samples from high concentrate-fed animals tended $(p<0.10)$ to show greater peak numbers and Shannon index values than those isolated from high forage-fed animals with ARISA, but no differences were identified with DGGE. The SAB samples from high concentrate-fed animals had lower $(p<0.05)$ peak numbers and Shannon index values than those from animals fed high-forage diets with ARISA, but only a trend was noticed for these parameters with DGGE $(p<0.10)$. The ARISA detected that animals fed alfalfa hay diets showed lower $(p<0.05)$ SAB diversity than those fed grass hay diets, but no differences were observed with DGGE. No effect of forage type on LAB diversity was detected by any technique. In this study, ARISA detected some changes in ruminal bacterial communities that were not detected by DGGE, and therefore ARISA was considered more appropriate for assessing bacterial diversity of ruminal bacterial pellets. The results highlight the impact of the fingerprinting technique used to draw conclusions on dietary factors affecting bacterial diversity in ruminal bacterial pellets.
\end{abstract}




\section{Introduction}

Rumen microorganisms are the most important source of amino acids for the host ruminant, and quantifying rumen protein synthesis is therefore a key point in feeding systems for ruminants. Methods for quantifying rumen microbial protein synthesis rely on the use of a bacterial pellet as a reference; this pellet is generally isolated from the liquid fraction of the rumen contents, because liquid-associated bacteria (LAB) are easier to isolate than solid-associated bacteria (SAB), despite $\mathrm{SAB}$ are usually the predominant bacterial fraction in the rumen (Merry and McAllan 1983). Moreover, the type of bacterial pellet used as a reference ( $S A B$ vs. LAB) can generate even greater differences than those promoted by the nature of the diet fed to animals (Carro and Miller 2002; Belanche et al. 2011). Differences in chemical composition and purine bases $(\mathrm{PB})$ :nitrogen $(\mathrm{N})$ ratio between $\mathrm{LAB}$ and $\mathrm{SAB}$ are widely demonstrated (MolinaAlcaide et al. 1996, 2009; Yang et al. 2001; Ipharraguerre et al. 2007), but their origin is still not clear, although it has been suggested that could be due to differences in the bacterial species present in the pellets (Martínez et al. 2009; Belanche et al. 2012).

Studies analysing the influence of dietary factors on bacterial diversity in LAB and SAB in cattle (Huws et al. 2010; Petri et al. 2012) and small ruminants (Sadet et al. 2007; Cunha et al. 2011; Saro et al. 2014) have reported contrasting results. This inconsistency can be due to a number of factors, such as the type of diet fed to the animals or the pellets isolation procedures, but it can also be due to some degree to the fingerprinting technique used in different studies. Although the use of next-generation sequencing techniques has gained importance during the last decade, several fingerprinting techniques, such as the denaturing gradient gel electrophoresis (DGGE) and the automated ribosomal intergenic spacer analysis (ARISA), among others, are still been used to assess bacterial diversity in the rumen. In addition, some studies have demonstrated a high correlation between the results of next-generation sequencing techniques and some fingerprinting techniques in terms of richness and diversity (De La Fuente et al. 2014; Van Dorst et al. 2014). To our best knowledge, no study has compared ARISA and DGGE techniques to assess diversity in bacterial pellets isolated from the rumen contents, and the main objective of this work was to investigate whether both techniques provided the same information regarding the influence of dietary factors on bacterial community structure in $\mathrm{LAB}$ and $\mathrm{SAB}$ pellets isolated from the rumen contents of small ruminants. Additionally, the relationships between bacterial diversity and chemical composition of bacterial pellets were studied.

\section{Materials and methods}

\subsection{Diets, animals and experimental procedures}

This study was conducted with a trial investigating nutrient utilisation and $\mathrm{N}$ balance in sheep and goats, and complementary data on dietary ingredients, feed intake, diet digestibility and $\mathrm{N}$ balance have already been published (Carro et al. 2012). Animal management and sampling were carried out by trained personnel, and animals were cared for and handled in accordance with the Spanish guidelines for experimental animal protection (Royal Decree 1201/2005 of Oct. 10 on the protection of animals used for experimentation or other scientific purposes) according to European 
Table 1. Chemical composition [ $\mathrm{g} / \mathrm{kg}$ dry matter unless otherwise stated] of the experimental diets with forage to concentrate ratios of 70:30 (HF) or 30:70 (HC) and alfalfa hay $(A)$ or grass hay $(G)$ as forage.

\begin{tabular}{lcccc}
\hline & HFA & HCA & HFG & HCG \\
\hline Dry matter [g/kg fresh matter] & 927 & 925 & 925 & 924 \\
Organic matter & 913 & 913 & 927 & 919 \\
Crude protein & 168 & 177 & 121 & 160 \\
Neutral detergent fibre & 426 & 374 & 499 & 401 \\
Acid detergent fibre & 269 & 187 & 238 & 174 \\
\hline
\end{tabular}

Regulations (European Directive 86/609). Four experimental diets with forage to concentrate ratios of 70:30 (HF) or 30:70 (HC) and either alfalfa hay (A) or grass hay (G) as forage were formulated. The concentrate was based on barley, gluten feed, wheat middlings, soybean meal, palmkern meal, wheat, corn and mineral-vitamin premix in the proportions of $215,204,200,135,115,50,50$ and $31 \mathrm{~g} / \mathrm{kg}$, respectively (fresh matter basis). The chemical composition of the diets is shown in Table 1.

Two Merino sheep $(55.1 \pm 2.90 \mathrm{~kg})$ and two Murciano-Granadina goats $(44.5 \pm 1.00 \mathrm{~kg})$, each provided with a permanent rumen cannula, were fed four diets in a $4 \times 4$ Latin square design with four 31-d periods. Diets were offered to animals twice daily $(08: 00$ and $18: 00 \mathrm{~h}$ ) at a daily rate of $56 \mathrm{~g}$ dry matter $(\mathrm{DM}) / \mathrm{kg}$ body weight ${ }^{0.75}$ to minimise feed selection. Animals were housed in individual pens and had continuous access to fresh water and vitamin/mineral blocks over the experimental periods.

On d 30 and 31 of each period, rumen contents (about $400 \mathrm{~g}$ ) was withdrawn from each animal at $2 \mathrm{~h}$ after the morning feeding and squeezed through four layers of cheesecloth. The $\mathrm{pH}$ of the fluid was immediately measured, $5 \mathrm{ml}$ of fluid were added to $5 \mathrm{ml}$ of deproteinising solution ( $20 \mathrm{~g}$ of metaphosphoric acid and $4 \mathrm{~g}$ of crotonic acid per 1) for volatile fatty acid (VFA) analysis, $2 \mathrm{ml}$ were added to $2 \mathrm{ml} 0.5 \mathrm{M} \mathrm{HCl}$ for $\mathrm{NH}_{3}-\mathrm{N}$ analysis, and samples were immediately frozen $\left(-20^{\circ} \mathrm{C}\right)$. The solid rumen digesta was further combined with an equal volume of saline solution $(0.9 \% \mathrm{NaCl})$ at $39^{\circ} \mathrm{C}$, mixed gently, and squeezed again to remove residual non-attached bacteria and protozoa. The whole filtrate was mixed with the rumen fluid obtained previously, kept at $4^{\circ} \mathrm{C}$ for $24 \mathrm{~h}$ and used to isolate LAB by differential centrifugation following the procedure described by Ramos et al. (2009). The remaining solid digesta was treated with saline solution $(0.9 \% \mathrm{NaCl})$ containing $0.1 \%$ methylcellulose, as previously reported (Ramos et al. 2009), before isolation of SAB. In each period, bacterial pellets were composited by animal and sampling day to have two pellets per animal (1 SAB and $1 \mathrm{LAB}$ ). Bacterial pellets were lyophilised and ground to a fine powder with a mortar and pestle before analysis of $\mathrm{N}$ and purine bases (PB) content and DNA extraction for ARISA and DGGE analyses.

\subsection{Extraction of DNA and DGGE and ARISA analyses}

The DNA was isolated in duplicate from LAB and SAB pellets (40 $\mathrm{mg}$ DM) following the repeated bead beating plus column procedure described by $\mathrm{Yu}$ and Morrison (2004). An additional step for treating the samples with cetyltrimethylammonium bromide was added to the procedure to remove PCR inhibitors. Absorbance ratios 
(A260:A280) of DNA samples were measured in a NanoDrop ${ }^{\circledR}$ ND-1000 Spectrophotometer NanoDrop Technologies, Wilmington, DE, USA) and were between 1.70 and 2.05 .

The V3 region of the $16 \mathrm{~S} r \mathrm{RNA}$ gene was amplified from the extracted DNA by PCR for DGGE analysis using the bacterial primers (338f forward 5'-CGC CCG CCG CGC GCG GCG GGC GGG GCG GGG GCA CGG GGG GCC 'TAC GGG AGG CAG CAG-3' and 534r reverse 5'- ATTACC GCG GCT GCT GG-30 (Muyzer et al. 1993). The PCR amplification followed the procedure described by Abecia et al. (2014). Briefly, the PCR reaction solution contained $50 \mathrm{ng}$ DNA in a $50 \mu \mathrm{l}$ mix containing $1 \mathrm{mM}$ buffer, $1.25 \mathrm{mM}$ of each primer, $0.8 \mathrm{mM}$ of dNTPs, $2.5 \mathrm{mM} \mathrm{MgCl}_{2}$ and $2.5 \mathrm{U}$ of Taq DNA polymerase in $10 \mathrm{mM}$ Tris $\mathrm{HCl}(\mathrm{pH} \mathrm{9.0)}$. The resulting amplicons were visualised on a $2 \%(\mathrm{w} / \mathrm{v}) \mathrm{TBE}$ ( $89 \mathrm{mM}$ Tris, $89 \mathrm{mM}$ Boric acid, $2 \mathrm{mM} \mathrm{Na}_{2}$ EDTA; $\mathrm{pH} \mathrm{8.3)} \mathrm{agarose} \mathrm{gel} \mathrm{after} \mathrm{staining} \mathrm{with}$ ethidium bromide. The DGGE was performed using the $\mathrm{BDH}$ system from VWR International Ltd (UK). The PCR products $(10 \mu \mathrm{l})$ were loaded onto $8 \%(\mathrm{w} / \mathrm{v})$ TAE polyacrylamide gels $(40 \mathrm{mmol} / 1$ of Tris base, $20 \mathrm{mmol} / 1$ of acetic acid and $1 \mathrm{mmol} / \mathrm{l}$ of EDTA, pH 8.3), which contained $40-60 \%$ of denaturant gradient ( $100 \%$ denaturant, $7 \mathrm{~mol} / \mathrm{l}$ of urea and $40 \%(\mathrm{vol} / \mathrm{vol})$ of deionised formamide). Electrophoresis was performed at a constant voltage of $100 \mathrm{~V}$ and temperature of $60^{\circ} \mathrm{C}$ for $16 \mathrm{~h}$. The DNA was visualised by silver staining with a Bio-Rad Silver stain kit, scanned DGGE images were analysed with the Quantity One Software (BioRad, Madrid, Spain) and the image was analysed with Quantity One Software (BIO-RAD Laboratories, Ltd, Hemel Hempsteads, Hearts, UK) by scoring for the presence or absence of bands at different positions in each line.

For ARISA, internal transcribed spacer was amplified from DNA using universal bacterial primers $16 \mathrm{~S}-1392 \mathrm{~F}$ and 23S-125R (Danovaro et al. 2006). Primer 23S-125R was fluorescently labelled with the phosphoramidite dye 6-FAM and ARISA technique was performed as described by Saro et al. (2014). Briefly, $5 \mathrm{ng}$ of amplicon were mixed with an internal size standard (GS 1200 LIZ; Applied Biosystems, Foster City, CA) in deionised formamide, then denatured at $94^{\circ} \mathrm{C}$ for $2 \mathrm{~min}$, and immediately chilled on ice. Automated detection of fragments was performed using an ABI Prism 3130 Genetic Analyzer (Applied Biosystems) with $36-\mathrm{cm}$ by $50-\mu \mathrm{m}$ capillary and POP-7 polymer. Peaks were identified by comparison with the internal size standard using the GeneMaker Software v1.80 (SoftGenetics, State College, PA) with a threshold of 100 fluorescence units to include the maximum number of peaks while excluding background fluorescence.

\subsection{Chemical analyses, calculations and statistical analyses}

DM (ID 934.01), ash (ID 942.05), crude protein (CP, method ID 984.13) and acid detergent fibre (ADF; ID 973.18) content in the diets were determined according to the Association of Official Analytical Chemists (2005). Analyses of neutral detergent fibre (NDF) were carried out according to Van Soest et al. (1991) using an ANKOM220 Fibre Analyzer unit (ANKOM Technology Corporation, Fairport, NY, USA). Sodium sulphite and heat-stable amylase were used in the analysis of NDF. Both NDF and ADF were expressed exclusive of residual ash.

Procedures for analysis of concentrations of VFA and $\mathrm{NH}_{3}-\mathrm{N}$ in ruminal fluid have been described by Carro et al. (2012). The concentration of PB in LAB and SAB pellets 
was quantified by HPLC after acid hydrolysis with $2 \mathrm{ml}$ of $2 \mathrm{M}$ perchloric acid at $100^{\circ} \mathrm{C}$ for $1 \mathrm{~h}$ as described by Martín-Orúe et al. (1998).

Analysis of ARISA peaks and DGGE band profiles was performed with the MVSP v3.12d software (Kovach Computing Service, Anglesey, UK), and it was considered that the peak/band profile reflects the predominant bacterial species or populations present in the pellets. The Shannon diversity index (Shannon and Weaver 1949) was calculated for the presence/absence of ARISA peaks and DGGE bands and used to evaluate the diversity of bacterial communities. Similarities between the peaks/bands profiles of the experimental samples were analysed using the Pearson correlation and displayed graphically as a dendrogram. The clustering algorithm used to calculate the dendrograms was an unweighted pair-group method with arithmetic averages in the MVSP v3.12d software. For both techniques, dendrograms were constructed separately for each animal.

Finally, in order to explore the relationships between bacterial diversity and either chemical composition of bacterial pellets or the fermentative parameters, a canonical correspondence analysis (CCA) was conducted for ARISA profiles using the R package vegan (Oksanen et al. 2016). This analysis allows identification of the shared biological trends within the two data sets. The Monte-Carlo permutation test and RV coefficient were used to confirm the relationships between the different data sets, assuming a $p$ value $<0.05$ (R package ade4; Dray and Dufour 2007)

Data on the number of peaks/bands and Shannon index were analysed independently for each fingerprinting technique and type of pellets as a mixed model using the PROC MIXED of SAS (SAS Inst. Inc., Cary, NC) with forage-to-concentrate ratio, forage type and forage-to-concentrate ratio $\times$ forage type as fixed effects, and animal as a random effect. Fermentation parameters and chemical composition of $L A B$ and $S A B$ pellets were analysed using the same model. Data obtained from the same animal in each period were averaged before statistical analysis. Differences between LAB and SAB composition were tested by a paired Student's $t$-test. Level of significance was established in $p<0.05$, and $p$-values between $>0.05$ and $<0.10$ were considered as trends.

\section{Results}

The diets used in this study were formulated to differ in their $\mathrm{N}$ and energy content with the objective of promoting different microbial growth in the rumen and therefore changes in bacterial diversity were expected.

\subsection{Bacterial diversity}

The mean values of the number of peaks/bands and Shannon index obtained from ARISA and DGGE, respectively, in LAB and SAB pellets from animals fed the experimental diets are shown in Table 2. The numbers of peaks in individual samples ranged from 48 to 99 for $L A B$ and from 41 to 95 for SAB with ARISA, whereas values of DGGE-bands ranged from 27 to 50 for LAB and from 18 to 45 for SAB. There was no forage to concentrate ratio $\times$ forage type interactions for these variables assessed either by ARISA or by DGGE. The LAB pellets from animals fed HC diets tended to have greater number of peaks $(p=0.076)$ and Shannon index values $(p=0.073)$ than those 
Table 2. Number of peaks or bands in the ARISA and DGGE analyses, respectively, and values of Shannon index of bacterial pellets isolated from the liquid (LAB) and solid (SAB) phase of the rumen contents of sheep and goats fed diets with forage to concentrate ratios $(F: C)$ of $70: 30$ (HF) or 30:70 $(\mathrm{HC})$ and alfalfa hay $(\mathrm{A})$ or grass hay $(\mathrm{G})$ as forage.

\begin{tabular}{|c|c|c|c|c|c|c|c|c|c|}
\hline & \multirow[b]{2}{*}{ Bacterial pellet } & \multicolumn{4}{|c|}{ Diet } & \multirow[b]{2}{*}{ SEM } & \multicolumn{3}{|c|}{$p$-Value } \\
\hline & & HFA & $\mathrm{HCA}$ & HFG & $\mathrm{HCG}$ & & $F: C$ & Forage type (FT) & $\mathrm{F}: \mathrm{C} \times \mathrm{FT}$ \\
\hline \multicolumn{10}{|l|}{ ARISA } \\
\hline \multirow[t]{2}{*}{ Number of peaks } & $\mathrm{LAB}$ & 62.3 & 76.8 & 69.8 & 75.8 & 5.11 & 0.076 & 0.541 & 0.427 \\
\hline & SAB & 71.3 & 65.8 & 76.6 & 66.0 & 1.89 & 0.026 & 0.035 & 0.973 \\
\hline \multirow[t]{2}{*}{ Shannon index } & LAB & 4.12 & 4.33 & 4.20 & 4.31 & 0.077 & 0.073 & 0.732 & 0.503 \\
\hline & SAB & 4.23 & 4.16 & 4.30 & 4.09 & 0.025 & 0.023 & 0.033 & 0.849 \\
\hline Similarity index & LAB-SAB & 53.4 & 61.5 & 60.6 & 59.5 & 2.40 & 0.303 & 0.172 & 0.088 \\
\hline \multicolumn{10}{|l|}{ DGGE } \\
\hline \multirow[t]{2}{*}{ Number of bands } & LAB & 35.5 & 36.8 & 30.5 & 27.8 & 3.74 & 0.846 & 0.110 & 0.606 \\
\hline & $S A B$ & 40.5 & 27.5 & 31.5 & 30.5 & 3.36 & 0.067 & 0.395 & 0.120 \\
\hline \multirow{2}{*}{ Shannon index } & $\mathrm{LAB}$ & 3.44 & 3.60 & 3.41 & 3.28 & 0.138 & 0.926 & 0.238 & 0.306 \\
\hline & SAB & 3.67 & 3.24 & 3.45 & 3.40 & 0.115 & 0.060 & 0.725 & 0.117 \\
\hline Similarity index & LAB-SAB & 49.8 & 45.0 & 47.6 & 41.6 & 4.02 & 0.517 & 0.235 & 0.896 \\
\hline
\end{tabular}

from animals fed HF diets when analysed by ARISA, but DGGE failed to detect effects of forage to concentrate ratio on LAB diversity. Greater number of peaks $(p=0.026)$ and Shannon index values $(p=0.023)$ were detected in SAB pellets from HF-fed animals than in those from HC-fed animals by ARISA, but only a trend $(p=0.067$ and 0.060 , respectively) was noticed by using DGGE. No effects of forage type on bacterial diversity of $L A B$ and $S A B$ were detected with DGGE, but a trend $(p<0.10)$ to greater $\mathrm{SAB}$ diversity in animals fed grass hay compared with those fed alfalfa hay was observed by ARISA. The similarity index between LAB and SAB ranged from $40.0 \%$ to $78.1 \%$ for ARISA and from $31.6 \%$ to $66.7 \%$ for DGGE, but these values were not affected by either forage-to-concentrate ratio or forage type with any technique.

When comparing SAB and LAB pellets in paired $t$ tests within each animal, there were no differences in the number of peaks/bands or Shannon index either with ARISA or with DGGE. The number of peaks in ARISA was greater $(p<0.001)$ than the number of DGGE bands, which resulted in greater $(p<0.001)$ Shannon index values for ARISA than for DGGE (4.23 and 3.51, respectively; values across diets). There was no relationship either between the number of ARISA-peaks and the DGGE bands or the Shannon index values for ARISA and those for DGGE.

Figure 1 shows the dendrograms of the ARISA and the DGGE profiles of SAB and LAB samples from individual animals fed the four experimental diets. The ARISA dendrograms showed a clear discrimination according to forage-to-concentrate ratio in the diet in animals 2 and 4, for which HF and HC samples formed two large clusters. Within each major cluster, samples from the same forage grouped together in animal 2 independently of the pellet type, and samples from animal 4 subclustered according to type of pellet ( $\mathrm{LAB}$ and $\mathrm{SAB}$ ). For animal 1, all HC samples grouped together, forming two subclusters according to forage type, but no clear clustering was observed for animal 3. For DGGE, LAB and SAB samples formed two large clusters in animal 2 and subclustered according to forage type. All SAB samples clustered together in animal 4 , and three out of four $S A B$ samples grouped in the same cluster in animal 1. As observed for ARISA, no clear pattern of clustering was detected for samples from animal 3. 


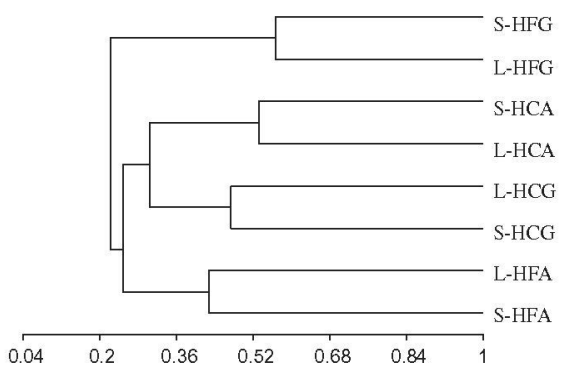

Animal 2 (Sheep) ARISA

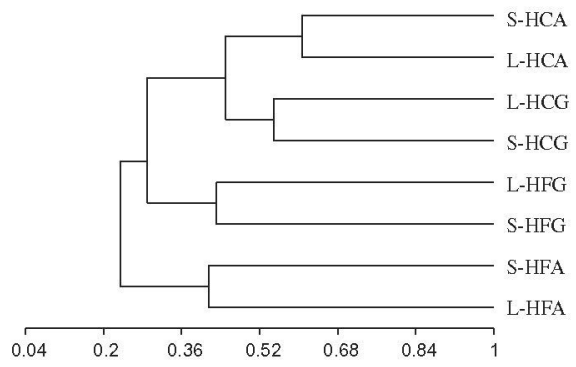

Animal 3 (Goat) ARISA

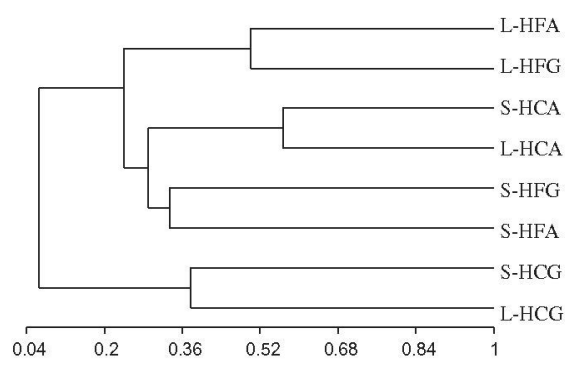

Animal 4 (Goat) ARISA

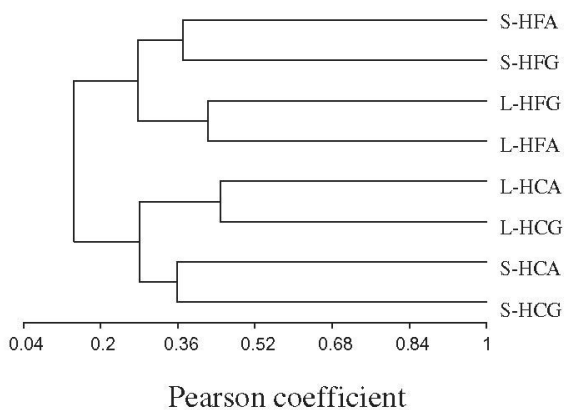

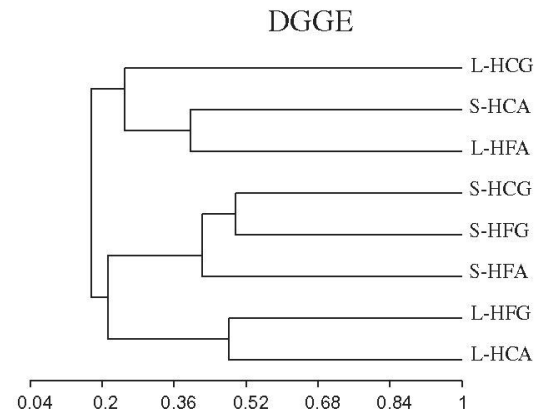

DGGE

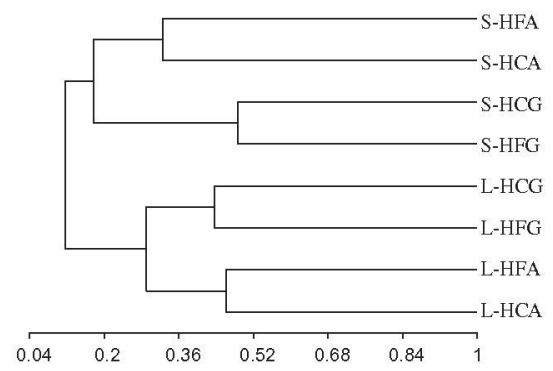

DGGE

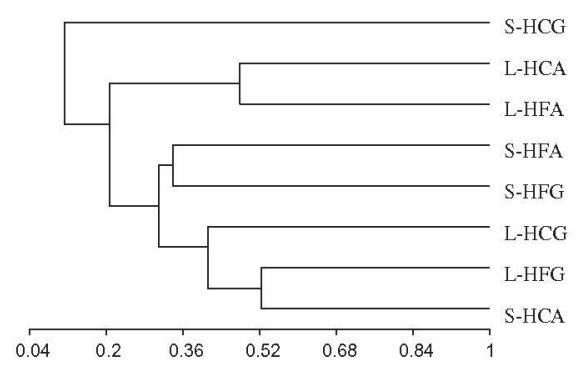

DGGE

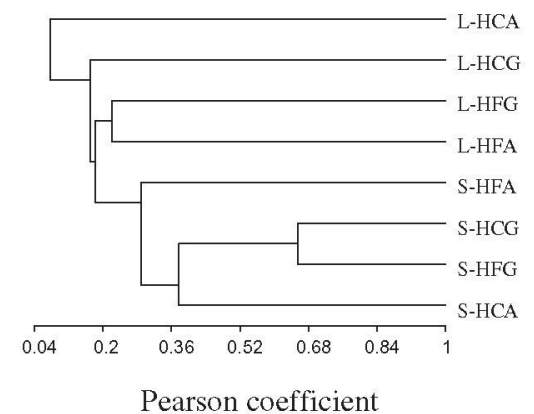

Pearson coefficient

Figure 1. Dendrograms of automated ribosomal intergenic spacer analysis (ARISA) and denaturing gradient gel electrophoresis (DGGE) profiles of bacterial pellets isolated from the solid (S) and liquid (L) phase of rumen contents from small ruminants fed diets with forage:concentrate ratios of 70:30 $(\mathrm{HF})$ or 30:70 $(\mathrm{HC})$ and alfalfa hay $(\mathrm{A})$ or grass hay $(\mathrm{G})$ as forage. Dendrograms correspond to samples isolated from each individual animal (animals 1-4). 


\subsection{Fermentation parameters and composition of bacterial pellets}

As shown in Table 3, forage-to-concentrate ratio $\times$ forage type interactions were detected only for ammonia-N concentrations $(p=0.007)$ and molar proportions of valerate $(p=0.044)$ in the rumen. Animals fed the HC diets had lower rumen $\mathrm{pH}$ values $(p=0.011)$, greater proportions of butyrate $(p=0.024)$ and tended to show lower acetate proportions $(p=0.069)$ than those fed the HF diets. The type of forage only affected the proportions of minor VFA, which were greater $(p=0.003$ to 0.019$)$ for diets containing alfalfa hay compared with those containing grass hay, likely due to greater protein degradation of alfalfa hay.

Significant forage-to-concentrate ratio $\times$ forage type interactions were observed for all chemical composition fractions analysed in the pellets, with the exception of PB:N in LAB and $\mathrm{N}$ content in SAB (Table 3). Animals fed HF diets had LAB with greater $(p=0.011)$ $\mathrm{N}$ content and adenine:guanine ratios than those fed $\mathrm{HC}$ diets, as well as SAB with lower $\mathrm{PB}$ concentrations $(p=0.037)$ and PB:N ratio $(p=0.043)$. In contrast, only few differences were observed due to forage type. Animals fed diets with alfalfa hay showed

Table 3. Effects of dietary treatments on ruminal fermentation characteristics and chemical composition of bacterial pellets isolated at $2 \mathrm{~h}$ after feeding from the rumen contents of sheep and goats fed diets with forage to concentrate ratios $(\mathrm{F}: \mathrm{C})$ of $70: 30(\mathrm{HF})$ or $30: 70(\mathrm{HC})$ and alfalfa hay $(\mathrm{A})$ or grass hay $(G)$ as forage.

\begin{tabular}{|c|c|c|c|c|c|c|c|c|}
\hline & \multicolumn{4}{|c|}{ Diet } & \multirow[b]{2}{*}{ SEM } & \multicolumn{3}{|c|}{$p$-Value } \\
\hline & HFA & HCA & HFG & HCG & & $F: C$ & Forage type (FT) & $\mathrm{F}: \mathrm{C} \times \mathrm{FT}$ \\
\hline \multicolumn{9}{|l|}{ Fermentation parameters } \\
\hline $\mathrm{pH}$ & 6.62 & 6.40 & 6.51 & 6.30 & 0.060 & 0.011 & 0.132 & 0.874 \\
\hline Ammonia-N & 237 & 232 & 110 & 221 & 14.6 & 0.011 & 0.003 & 0.007 \\
\hline $\begin{array}{l}\text { Total volatile fatty } \\
\text { acids [mmol//] } \\
\text { Molar proportions } \\
\text { [mol } / 100 \text { mol] of: }\end{array}$ & 85.7 & 85.0 & 71.4 & 80.9 & 4.67 & 0.384 & 0.097 & 0.321 \\
\hline Acetate & 67.9 & 66.4 & 69.1 & 66.6 & 0.89 & 0.069 & 0.447 & 0.620 \\
\hline Propionate & 15.5 & 16.6 & 16.9 & 16.6 & 0.50 & 0.440 & 0.204 & 0.237 \\
\hline Butyrate & 11.5 & 12.5 & 10.9 & 13.2 & 0.55 & 0.024 & 0.995 & 0.277 \\
\hline Isobutyrate & 1.45 & 1.36 & 1.07 & 1.03 & 0.086 & 0.493 & 0.007 & 0.802 \\
\hline Isovalerate & 1.56 & 1.52 & 1.12 & 1.14 & 0.129 & 0.934 & 0.019 & 0.832 \\
\hline Valerate & 2.12 & 1.85 & 1.01 & 1.51 & 0.149 & 0.469 & 0.003 & 0.044 \\
\hline Acetate:Propionate & 4.40 & 4.05 & 4.12 & 4.03 & 0.156 & 0.209 & 0.376 & 0.440 \\
\hline \multicolumn{9}{|c|}{$\begin{array}{l}\text { Chemical composition of bacterial pellets } \\
\text { Liquid-associated } \\
\text { bacteria }[L A B]\end{array}$} \\
\hline Nitrogen $(\mathrm{N})[\mathrm{mg} / \mathrm{g}]$ & 70.4 & 65.6 & 69.4 & 68.4 & 0.80 & 0.011 & 0.322 & 0.057 \\
\hline $\begin{array}{l}\text { Purine bases (PB) } \\
{[\mu \mathrm{mol} / \mathrm{g}]}\end{array}$ & 69.9 & 58.7 & 63.9 & 69.2 & 2.21 & 0.052 & 0.106 & $<0.001$ \\
\hline $\begin{array}{l}\text { Adenine:guanine } \\
\text { [mg/mg] }\end{array}$ & 0.96 & 0.91 & 1.17 & 1.03 & 0.027 & 0.011 & 0.001 & 0.014 \\
\hline $\begin{array}{l}\text { PB:N [ } \mu \mathrm{mol} / \mathrm{mg}] \\
\text { Solid-associated } \\
\text { bacteria (SAB) }\end{array}$ & 0.99 & 0.90 & 0.93 & 1.02 & 0.027 & 0.964 & 0.324 & 0.182 \\
\hline $\mathrm{N}[\mathrm{mg} / \mathrm{g}]$ & 72.4 & 70.6 & 67.5 & 66.8 & 1.37 & 0.396 & 0.019 & 0.708 \\
\hline Purine bases $[\mu \mathrm{mol} / \mathrm{g}]$ & 64.4 & 62.8 & 54.4 & 68.0 & 2.32 & 0.037 & 0.310 & 0.015 \\
\hline $\begin{array}{l}\text { Adenine:guanine } \\
{[\mathrm{mg} / \mathrm{mg}]}\end{array}$ & 1.00 & 1.07 & 1.09 & 0.88 & 0.040 & 0.129 & 0.278 & 0.012 \\
\hline $\mathrm{PB}: \mathrm{N}[\mu \mathrm{mol} / \mathrm{mg}]$ & 0.89 & 0.89 & 0.80 & 1.03 & 0.044 & 0.043 & 0.649 & 0.043 \\
\hline
\end{tabular}


lower adenine:guanine ratios $(p=0.001)$ in LAB and greater $N$ content $(p=0.019)$ in $\mathrm{SAB}$ than those fed grass hay diets. In paired $t$ tests within each animal, LAB tended to have greater $\mathrm{PB}(p=0.093)$ and $\mathrm{PB} / \mathrm{N}$ ratio $(p=0.064)$ than $\mathrm{SAB}$, but there were no differences between both bacterial fractions in their $\mathrm{N}$ and adenine:guanine ratios.

CCA was used to evaluate the possible associations between the bacterial diversity assessed by ARISA and either the chemical composition of bacterial pellets (Figure 2) or fermentative variables (data not shown). The direction of each vector indicates an increasing value of the corresponding variable, and the angle between the vectors indicates the degree to which variables are correlated. Samples from SAB pellets show more dispersion over the graph than LAB samples, indicating a higher dissimilarity between the bacterial populations attached to solid particles and those in the liquid. As indicated by the length of the vectors, the ratios Ad:Gu and PB:N ratios had greater influence in the pattern of variation of bacterial populations. Most of the samples from animals fed $\mathrm{HC}$ diets seem to be positioned on the left of the graph, being related to higher amounts of $\mathrm{PB}$ and higher $\mathrm{PB}: \mathrm{N}$ ratio, whereas samples from animals fed $\mathrm{HF}$ diets are positioned in the part of the graph related to higher Ad:Gu ratio and lower $\mathrm{PB}$ concentration and $\mathrm{PB}: \mathrm{N}$ ratios. These results would agree with the difference in bacteria

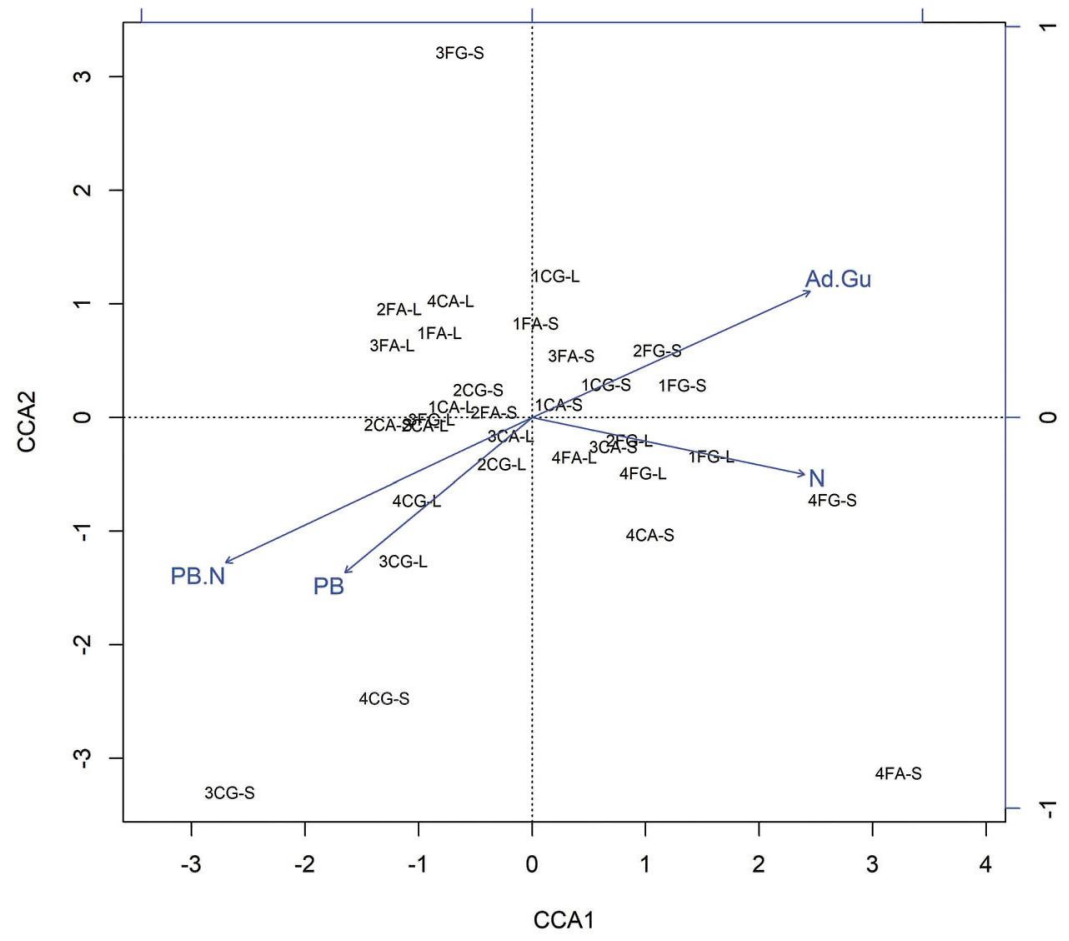

Figure 2. Diagram of canonical correspondence analysis of bacterial diversity assessed by ARISA and chemical composition of bacterial pellets (vectors) from the liquid $(L)$ or solid $(S)$ phase of the rumen contents of sheep (animals 1 and 2) and goats (animals 3 and 4) fed diets with forage to concentrate ratios of 70:30 (F) or 30:70 (C) and either alfalfa hay $(A)$ or grass hay $(G)$ as forage. The direction of each vector indicates an increasing value of that variable, the angle between the vectors indicates the degree to which the variables are correlated, and the magnitude of the vectors determines the importance of that variable to classify the samples. PB: purine bases; N: nitrogen; Ad:Gu: adenine: guanine ratio. 
diversity found by ARISA in SAB and LAB pellets attributed to forage-to-concentrate ratio. However, the Monte-Carlo permutation test $(p=0.402$; $\mathrm{RV}=0.18$; 999 permutations) showed no clear correlation between the bacterial diversity determined by ARISA and the chemical composition of the bacterial pellets. Regarding the association of bacterial diversity and fermentative variables $(p=0.006$; $\mathrm{RV}=0.36$ for $\mathrm{LAB} ; p=0.009$; $\mathrm{RV}=0.37$ for $\mathrm{SAB} ; 999$ permutations), VFA and ammonia concentrations were the most associated variables with the pattern of distribution of samples (figure not shown).

\section{Discussion}

\subsection{Bacterial diversity}

Rumen fermentation in sheep and goats fed the same diets has been extensively investigated, and minor differences were reported when animals were fed medium-togood-quality diets, but important differences were detected when animals received lowquality diets (Molina-Alcaide et al. 2000; Carro et al. 2012). In the present study, two animals of each animal species were fed diets of variable quality with the aim of increasing the variation in bacterial diversity in the rumen. Because the main objective of this study was to compare the ability of ARISA and DGGE techniques to detect shifts in bacterial diversity in ruminal pellets due to diets, the effects of dietary factors were analysed independently for each technique. Both forage-to-concentrate ratio and forage type have been previously identified as factors influencing bacterial diversity in the rumen, although results from different studies are controversial. Our ARISA results clearly indicate that bacterial diversity in SAB was affected by forage type. Similarly, Koike et al. (2003) observed that bacteria isolated from orchardgrass were different from those isolated from alfalfa when samples of both forages were incubated in sacco in the rumen of sheep as assessed by bacterial 16S rDNA cloning, and Pitta et al. (2010) reported that feeding bermudagrass hay to steers promoted greater bacterial diversity in their solid ruminal digesta than feeding winter wheat forage. Differences in bacterial diversity might indicate an adaptation of ruminal bacteria in response to the physicochemical composition of the forages. In contrast, the DGGE did not detect significant differences in bacterial diversity in SAB or LAB pellets due to forage type in our study. Similarly, Huws et al. (2010) reported no differences in the DGGE-band number in $L A B$ and $S A B$ pellets isolated from the rumen of steers fed red clover or grass silage.

No effect of forage-to-concentrate ratio on bacterial diversity was observed in LAB pellets, but ARISA detected higher diversity in SAB pellets isolated from HF-fed animals than in those from HC-fed animals, and a trend to the same response was detected by DGGE. This is in accordance with Larue et al. (2005), who reported that bacterial diversity in SAB tended to be greater in sheep fed only orchardgrass hay than in sheep fed a 70:30 orchardgrass:concentrate diet as assessed by ribosomal intergenic spacer analysis. In contrast, Petri et al. (2012) and Kocherginskaya et al. (2001), both using DGGE, observed higher bacterial diversity in the rumen of steers fed diets containing concentrate than in those fed only forage. Differences in the chemical composition and characteristics of the forages and concentrates, level of feeding and sampling time, among other factors, may contribute to the conflicting results observed in different studies. 
When DGGE was used to assess bacterial diversity, samples from SAB and LAB grouped together in the dendrograms of two animals, with no further subclustering according to other factors. Similarly, Mosoni et al. (2011) observed that samples from solid and liquid phases of the rumen of forage-fed wethers separated into two distinct clusters in DGGE dendrograms, which was attributed to the increased proportion of fibre-degrading bacteria associated with feed particles reported for forage-based diets, but no clear subclustering was observed according to other factors. In contrast, no clear pattern of clustering according to ruminal phase was observed in ARISA dendrograms in our study, but samples from two animals grouped according to forage-to-concentrate ratio and then subclustered according to forage type. These results indicate that the effect of the diet on bacterial community structure was greater than the influence of rumen contents phase. The differences between both techniques could be due to the greater sensitivity of ARISA compared to DGGE, as it has been previously shown in soil (Cherif et al. 2008) and samples of the whole rumen contents in sheep fed high-forage diets (Saro et al. 2014). Furthermore, the greater number of peaks revealed by ARISA probably reflects the higher resolution of capillary electrophoresis and the greater sensitivity to detect the fluorescently labelled PCR products, compared with DGGE (Talbot et al. 2008), a technique which relies on electrophoresis through relatively lowresolution gels. In addition, the DGGE technique amplifies a short fragment (about 500 $\mathrm{bp)}$ of the gene coding for the 16S rRNA, whereas ARISA contains the intergenic sequence flanked by the $16 \mathrm{~S}$ and $23 \mathrm{~S}$ rRNA genes, ranging from 100 to $1500 \mathrm{bp}$, known to be highly variable, and often encoding tRNAs (Saro et al. 2014). As pointed out by others (Fromin et al. 2002; Loisel et al. 2006), bacterial biodiversity measured with DGGE should be interpreted with caution, as there is a limit in the number of operational taxonomic units (bands) that can be visualised in a gel and thus the contribution to diversity of less-abundant taxons could be underestimated.

Few studies have compared bacterial diversity in solid and liquid phases of the rumen, and the results are inconsistent. In agreement with our results with both techniques, Belanche et al. (2012) observed no differences between LAB and SAB pellets isolated from the rumen of sheep fed either only alfalfa hay or mixed 1:1 with ground barley by using DGGE. In contrast, Huws et al. (2010) and Sadet et al. (2007), both also using DGGE, observed greater diversity in the solid than in the liquid phase of the rumen contents in lambs and steers fed forage-based diets, respectively. However, Cunha et al. (2011) reported greater bacterial diversity in the liquid than in the solid phase of the rumen in grazing goats by using cloning and sequencing $16 \mathrm{~S}$ rRNA. These contradictory results could be explained by differences in animal species, in the diet and sampling time, as bacterial diversity changes over the postprandial period (Welkie et al. 2010; Saro et al. 2014), but also by differences in the DNA extraction method. Moreover, it should be noted that whereas $\mathrm{LAB}$ are relatively easy to isolate and a great recovery of the bacterial populations should be expected, recovery of SAB from rumen contents is usually low, indicating that a mere SAB isolate may not be representative of the total SAB population (Ramos et al. 2009). The detachment method used in the present study recovered less than $40 \%$ of the total SAB in sheep fed high-forage diets (Ramos et al. 2009), but to our knowledge no other method has yet been proven to be more effective in removing $S A B$ from ruminal digesta. Similarity values between $\mathrm{LAB}$ and $\mathrm{SAB}$ in our study (ranging from $41.6 \%$ to $61.5 \%$; Table 2 ) were close to the 
$51 \%$ of operational taxonomic units shared between the two ruminal phases reported by Cunha et al. (2011) in grazing goats, although lower similarities (from $8 \%$ to $21 \%$ ) were observed by Kong et al. (2010) in the rumen of forage-fed cows.

\subsection{Fermentation parameters and composition of bacterial pellets}

Ruminal $\mathrm{pH}$ at $2 \mathrm{~h}$ after feeding did not drop below 6.15 in any animal. The restricted intake level and the low cereal content in the $\mathrm{HC}$ diets possibly contributed to prevent the rapid fall in pH usually observed in sheep fed HC diets (Carro et al. 2000). The lower $\mathrm{NH}_{3}-\mathrm{N}$ levels in the animals fed grass hay diets could be due to the lower crude protein intake and/or lower protein degradation than in animals fed alfalfa hay. The lack of differences between HF and HC diets in total VFA concentrations in rumen contents agrees well with the results of Carro et al. (2000) in sheep, although others (Pérez et al. 1996; Nocek 1997) have observed that the supplementation of forage diets with readily fermentable carbohydrates resulted in increased total VFA ruminal concentrations. However, it should be noted that VFA concentrations do not necessarily reflect VFA production rates, and the effect of forage to concentrate ratio on the VFA profile is unclear in the literature (Carro et al. 2000).

Available information on the effects of diet on chemical composition of LAB and SAB is inconsistent. In agreement with our results, other authors (Romero-Huelva and MolinaAlcaide 2013; Abecia et al. 2014) reported that feeding different diets to goats resulted in changes in guanine and $\mathrm{N}$ concentration in LAB. In contrast, Molina-Alcaide et al. (2009) observed an influence of diet on $\mathrm{PB}: \mathrm{N}$ ratio in $\mathrm{SAB}$, but not in $\mathrm{LAB}$. Greater $\mathrm{PB}$ concentrations and $\mathrm{PB}: \mathrm{N}$ ratios in $\mathrm{LAB}$ compared to $\mathrm{SAB}$ have been reported in several studies (Martín-Orúe et al. 1998; Carro and Miller 2002; Molina-Alcaide et al. 2009), which was attributed to the existence of different bacterial species in each fraction and to the lower growth rate of SAB (Obispo and Dehority 1999). On the contrary, Belanche et al. (2011) observed that $S A B$ from lambs fed diets differing in forage-to-concentrate ratio had lower $\mathrm{PB}: \mathrm{N}$ ratios than $\mathrm{LAB}$ and attributed these results to the greater metabolic activity and preferential $\mathrm{NH}_{3}-\mathrm{N}$ uptake of LAB compared with $\mathrm{SAB}$.

Obispo and Dehority (1999) associated changes in PB content in bacterial pellets to the presence of different species with different growth rates. This is in agreement with the results showed by the CCA in the present study, as chemical composition of the pellets was not related to the bacterial diversity assessed by ARISA. The ARISA technique was used to detect the presence or absence of different bacterial operational taxonomic units, but no information on microbial growth rate and/or activity was provided. In addition, although diet can affect bacterial diversity in ruminal pellets, their chemical composition would depend on more factors, such as the abundance of certain bacterial groups.

In summary, our results with both fingerprinting techniques indicate that bacterial diversity in bacterial pellets isolated from the solid and liquid rumen contents of small ruminants was influenced by the type of forage included in the diet, although ARISA identified more significant differences than DGGE. In addition, ARISA detected changes in bacterial communities due to the forage to concentrate ratio in the diet that were not detected by DGGE. For that reasons, ARISA was considered more appropriate for evaluating bacterial diversity of ruminal pellets. The observed differences between the two techniques can help to explain the controversial results reported in the literature on 
the influence of dietary factors on rumen bacterial diversity when assessed by different methods. Finally, bacterial diversity was not related to chemical composition of the bacterial pellets, but it was related to rumen fermentation parameters.

\section{Acknowledgement}

The authors thank Dr. B. Rabanal for his help with ARISA analyses and J. Fernández for technical assistance.

\section{Disclosure statement}

No potential conflict of interest was reported by the authors.

\section{Funding}

This work was supported by the Spanish Ministry of Economy, Industry and Competitiveness under [grant number AGL2011-22628].

\section{ORCID}

Leticia Abecia (D) http://orcid.org/0000-0003-4097-8903

\section{References}

Abecia L, Soto EC, Ramos-Morales E, Molina-Alcaide E. 2014. Microbial and chemical composition of liquid-associated bacteria in goats' rumen and fermenters. J Anim Physiol Anim Nutr. 98:1001-1012.

Association of Official Analytical Chemists. 2005. Official Methods of Analysis, 18th ed. Gaithersburg (MD, USA): AOAC Chemists.

Belanche A, Abecia L, Holtrop G, Guada JA, Castrillo C, De La Fuente G, Balcells J. 2011. Study of the effect of presence or absence of protozoa on rumen fermentation and microbial protein contribution to the chyme. J Anim Sci. 89:4163-4174.

Belanche A, Doreau M, Edwards JE, Moorby JM, Pinloche E, Newbold CJ. 2012. Shifts in the rumen microbiota due to the type of carbohydrate and level of protein ingested by dairy cattle are associated with changes in rumen fermentation. J Nutr. 142:1684-1692.

Carro MD, Cantalapiedra-Hijar G, Ranilla MJ, Molina-Alcaide E. 2012. Urinary excretion of purine derivatives, microbial protein synthesis, nitrogen use, and ruminal fermentation in sheep and goats fed diets of different quality. J Anim Sci. 90:3963-3972.

Carro MD, Miller EL. 2002. Comparison of microbial markers $\left(\mathrm{N}^{15}\right.$ and purine bases) and bacterial isolates for the estimation of rumen microbial protein synthesis. Anim Sci. 75:315-321.

Carro MD, Valdés C, Ranilla MJ, González JS. 2000. Effect of forage to concentrate ratio in the diet on ruminal fermentation and digesta flow kinetics in sheep offered food at a fixed and restricted level of intake. Anim Sci. 70:127-134.

Cherif H, Ouzari H, Marzorati M, Brusetti L, Jedidi N, Hassen A, Daffonchio A. 2008. Bacterial community diversity assessment in municipal solid waste compost amended soil using DGGE and ARISA fingerprinting methods. World J Microbiol Biotechnol. 24:1159-1167.

Cunha IS, Barreto CC, Costa OYA, Bomfim MA, Castro AP, Kruger RH, Quirino BF. 2011. Bacteria and Archaea community structure in the rumen microbiome of goats (Capra hircus) from the semiarid region of Brazil. Anaerobe. 17:118-124. 
Danovaro R, Luna GM, Dell'Anno A, Pietrangeli B. 2006. Comparison of two fingerprinting techniques, terminal restriction fragment length polymorphism and automated ribosomal intergenic spacer analysis, for determination of bacterial diversity in aquatic environments. Appl Environ Microbiol. 72:5982-5989.

De La Fuente G, Belanche A, Girwood SE, Pinloche E, Wilkinson T, Newbold CJ. 2014. Pros and cons of ion-torrent next generation sequencing versus terminal restriction fragment length polymorphism T-RFLP for studying the rumen bacterial community. PLoS ONE. 9(7): e101435.

Dray S, Dufour AB. 2007. The ade4 package: implementing the duality diagram for ecologists. J Stat Softw. 22:1-20.

Fromin N, Hamelin J, Tarnawski S, Roesti D, Jourdain-Miserez K, Forestier N, Teyssier-Cuvelle S, Gillet F, Aragno M, Rossi P. 2002. Statistical analysis of denaturing gel electrophoresis (DGE) finger- printing patterns. Environ Microbiol. 4:634-643.

Huws SA, Lee MRF, Muetzel SM, Scott MB, Wallace RJ, Scollan ND. 2010. Forage type and fish oil cause shifts in rumen bacterial diversity. FEMS Microbiol Ecol. 73:396-407.

Ipharraguerre IR, Reynal SM, Liñeiro M, Broderick GA, Clark JH. 2007. A comparison of sampling sites, digesta and microbial markers, and microbial references for assessing the postruminal supply of nutrients in dairy cows. J Dairy Sci. 90:1904-1919.

Kocherginskaya SA, Aminov RI, White BA. 2001. Analysis of the rumen bacterial diversity under two different diet conditions using denaturing gradient gel electrophoresis, random sequencing, and statistical ecology approaches. Anaerobe. 7:119-134.

Koike S, Pan J, Kobayashi Y, Tanaka K. 2003. Kinetics of in sacco fiber-attachment of representative ruminal cellulolytic bacteria monitored by competitive PCR. J Dairy Sci. 86:14291435.

Kong Y, Teather R, Forster R. 2010. Composition, spatial distribution, and diversity of the bacterial communities in the rumen of cows fed different forages. FEMS Microbiol Ecol. 74:612-622.

Larue R, Yu Z, Parisi VA, Egan AR, Morrison M. 2005. Novel microbial diversity adherent to plant biomass in the herbivore gastrointestinal tract, as revealed by ribosomal intergenic spacer analysis and rrs gene sequencing. Environ Microbiol. 7:530-543.

Loisel P, Harmand J, Zemb O, Latrille E, Lobry C, Delgenes JP, Godon JJ. 2006. Denaturing gradient electrophoresis (DGE) and singlestrand conformation polymorphism (SSCP) molecular fingerprintings revisited by simulation and used as a tool to measure microbial diversity. Environ Microbiol. 8:720-731.

Martínez ME, Ranilla MJ, Ramos S, Tejido ML, Saro C, Carro MD. 2009. Evaluation of procedures for detaching particle-associated microbes from forage and concentrate incubated in Rusitec fermenters: efficiency of recovery and representativeness of microbial isolates. $\mathbf{J}$ Anim Sci. 87:2064-2072.

Martín-Orúe S, Balcells J, Zakraoui F, Castrillo C. 1998. Quantification and chemical composition of mixed bacteria harvested from solid fractions of rumen digesta: effect of detachment procedure. Anim Feed Sci Technol. 71:269-282.

Merry RJ, McAllan AB. 1983. A comparison of the chemical composition of mixed bacteria harvested from the liquid and solid fractions of rumen digesta. Br J Nutr. 50:701-709.

Molina-Alcaide E, Martín-García I, Aguilera JF. 2000. A comparative study of nutrient digestibility, kinetics of degradation and passage and rumen fermentation pattern in goats and sheep offered good quality diets. Livest Prod Sci. 64:215-223.

Molina-Alcaide E, Pascual MR, Cantalapiedra-Hijar G, Morales-García EY, Martín-García AI. 2009. Effects of concentrate replacement by feed blocks on ruminal fermentation and microbial growth in goats and single-flow continuous-culture fermenters. J Anim Sci. 87:1321-1333.

Molina-Alcaide E, Weisbjerg MR, Hvelplund T. 1996. Degradation characteristics of shrubs and the effect of supplementation with urea or protein on microbial production using a continuous-culture system. J Anim Physiol Anim Nutr. 75:121-132. 
Mosoni P, Martin C, Forano E, Morgavi DP. 2011. Long-term defaunation increases the abundance of cellulolytic ruminococci and methanogens but does not affect the bacterial and methanogen diversity in the rumen of sheep. J Anim Sci. 89:783-791.

Muyzer G, De Waal EC, Uitterlinden AG. 1993. Profiling of complex microbial populations by denaturing gradient gel electrophoresis analysis of polymerase chain reaction-amplified genes coding for 16S rRNA. Appl Environ Microbiol. 59:695-700.

Nocek JE. 1997. Bovine acidosis: implications on laminitis. J Dairy Sci. 8:1005-1028.

Obispo NE, Dehority BA. 1999. Feasibility of using total purines as a marker for ruminal bacteria. J Anim Sci. 77:3084-3095.

Oksanen J, Blanchet FG, Friendly M, Kindt R, Legendre P, McGlinn D, Minchin PR, O'Hara RB, Simpson GL, Solymos P, et al. 2016. Package vegan: community Ecology Package [Internet]. R package version 2.4-1. [cited 2017 September 15]. Available from: http://CRAN.R-project.org/ package $=$ vegan .

Perez JF, Balcells J, Guada JA, Castrillo C. 1996. Determination of rumen microbial-nitrogen production in sheep: a comparison of urinary purine excretion with methods using ${ }^{15} \mathrm{~N}$ and purine bases as markers of microbial-nitrogen entering the duodenum. Br J Nutr. 75:699-709.

Petri RM, Forster RJ, Yang W, McKinnon JJ, McAllister TA. 2012. Characterization of rumen bacterial diversity and fermentation parameters in concentrate fed cattle with and without forage. J Appl Microbiol. 112:1152-1162.

Pitta DW, Pinchak W, Dowd S, Osterstock J, Gontcharova V, Youn E, Dorton K, Yoon I, Min DR, Fulford JD, et al. 2010. Rumen bacterial diversity dynamics associated with changing from Bermuda grass hay to grazed winter wheat diets. Microb Ecol. 59:511-522.

Ramos S, Tejido ML, Ranilla MJ, Martínez ME, Saro C, Carro MD. 2009. Influence of detachment procedure and diet on recovery of solid-associated bacteria from sheep ruminal digesta and representativeness of bacterial isolates as assessed by automated ribosomal intergenic spacer analysis-polymerase chain reaction. J Dairy Sci. 92:5659-5668.

Romero-Huelva M, Molina-Alcaide E. 2013. Nutrient utilization, ruminal fermentation, microbial nitrogen flow, microbial abundances, and methane emissions in goats fed diets including tomato and cucumber waste fruits. J Anim Sci. 91:914-923.

Sadet S, Martin C, Meunier B, Morgavi DP. 2007. PCR-DGGE analysis reveals a distinct diversity in the bacterial population attached to the rumen epithelium. Animal. 1:939-944.

Saro C, Ranilla MJ, Cifuentes A, Rosselló-Mora R, Carro MD. 2014. Technical note: comparison of automated ribosomal intergenic spacer analysis and denaturing gradient gel electrophoresis to assess bacterial diversity in the rumen of sheep. J Anim Sci. 92:1083-1088.

Shannon CE, Weaver W. 1949. The mathematical theory of communication. Urbana (IL, USA): University of Illinois Press.

Talbot G, Topp E, Palin MF, Massé DI. 2008. Evaluation of molecular methods used for establishing the interactions and functions of microorganisms in anaerobic bioreactors. Water Res. 42:513-537.

Van Dorst J, Bissett A, Palmer AS, Brown M, Snape I, Stark JS, Raymond B, Mckinlay J, Ji M, Winsley T, et al. 2014. Community fingerprinting in a sequencing world. FEMS Microbiol Ecol. 89:316-330.

Van Soest PJ, Robertson JB, Lewis BA. 1991. Methods for dietary fiber, neutral detergent fiber, and nonstarch polysaccharides in relation to animal nutrition. J Dairy Sci. 74:3583-3597.

Welkie DG, Stevenson DM, Weimer PJ. 2010. ARISA analysis of ruminal bacterial community dynamics in lactating dairy cows during the feeding cycle. Anaerobe. 16:94-100.

Yang WZ, Beauchemin KA, Rode LM. 2001. Effect of dietary factors on distribution and chemical composition of liquid- or solid-associated bacterial populations in the rumen of dairy cows. J Anim Sci. 79:2736-2746.

Yu Z, Morrison M. 2004. Improved extraction of PCR-quality community DNA from digesta and fecal samples. Biotechniques. 36:808-812. 